Article

\title{
Supplementation of Oilseeds to an Herbage Diet High in Condensed Tannins Affects Methane Production with Minimal Impact on Ruminal Fermentation in Continuous Culture
}

\author{
Eric D. Billman ${ }^{1,2}$, S. Leanne Dillard ${ }^{1,3}\left(\mathbb{D}\right.$, Ana Isabel Roca-Fernández ${ }^{1,4}$ (D) and Kathy J. Soder 1,*(D) \\ 1 USDA-ARS, Pasture Systems and Watershed Management Research Unit, University Park, PA 16802, USA; \\ eric.billman@usda.gov (E.D.B.); dillasa@auburn.edu (S.L.D.); anai.roca@usc.es (A.I.R.-F.) \\ 2 USDA-ARS, Coastal Plains Soil, Water, and Plant Conservation Research Unit, Florence, SC 29501, USA \\ 3 Department of Animal Sciences and Department of Crop, Soil, and Environmental Sciences, \\ Auburn University, Auburn, AL 36803, USA \\ 4 Departamento de Producción Vegetal y Proyectos de Ingeniería, Escuela Politécnica Superior de Ingeniería, \\ Universidad de Santiago de Compostela, 27002 Lugo, Spain \\ * Correspondence: kathy.soder@usda.gov; Tel.: +1-(814)-865-3158
}

Citation: Billman, E.D.; Dillard, S.L.; Roca-Fernández, A.I.; Soder, K.J. Supplementation of Oilseeds to an Herbage Diet High in Condensed Tannins Affects Methane Production with Minimal Impact on Ruminal Fermentation in Continuous Culture. Fermentation 2022, 8, 109. https:// doi.org/10.3390/fermentation8030109

Academic Editors: Yeong-Hsiang Cheng, Monika Stefaniuk-Szmukier and Qing Zhang

Received: 7 February 2022 Accepted: 28 February 2022 Published: 3 March 2022

Publisher's Note: MDPI stays neutral with regard to jurisdictional claims in published maps and institutional affiliations.

Copyright: (c) 2022 by the authors. Licensee MDPI, Basel, Switzerland. This article is an open access article distributed under the terms and conditions of the Creative Commons Attribution (CC BY) license (https:// creativecommons.org/licenses/by/ $4.0 /)$.

\begin{abstract}
Condensed tannins (CT) have been observed to reduce enteric $\mathrm{CH}_{4}$ production when added to ruminant diets. However, high concentrations of CT in forages such as sericea lespedeza (SL; Lespedeza cuneata (Dum. Cours.) G. Don) may depress nutrient digestibility. Oilseed crops, high in lipid concentration, also reduce enteric $\mathrm{CH}_{4}$ via toxicity to methanogenic bacteria with less depression of nutrient digestibility. However, it is unclear whether combining these two feeds would result in even greater decreases in $\mathrm{CH}_{4}$ without impairing ruminal fermentation. This study used an in vitro continuous culture fermentor system to determine if supplementation of ground oilseeds would further reduce enteric $\mathrm{CH}_{4}$ production while improving nutrient digestibility of high-CT forages. The experimental design was a $4 \times 4$ Latin square, with four diets containing (dry matter basis) 45\% orchardgrass (OCH; Dactylis glomerata L.), 45\% sericea lespedeza (SL; Lespedeza cuneata (Dum. Cours.) G. Don), and 10\% oilseed supplements, using canola (CAN; Brassica napus L.), soybean (SOY; Glycine max L.), sunflower (SUN; Helianthus annuus L.), or a mix of all three species (MIX; in equal proportions). Fermentors were fed $82 \mathrm{~g}$ of dry matter/d in four equal feedings over four $10 \mathrm{~d}$ periods. Methane was recorded every $10 \mathrm{~min}$, and effluent samples were analyzed for $\mathrm{pH}$, volatile fatty acids, dry matter, organic matter, crude protein, neutral detergent fiber, and acid detergent fiber to determine apparent and true nutrient digestibilities. The CAN, SUN, and MIX diets had greater concentrations of crude fat $(7-8 \mathrm{~g} / \mathrm{kg})$ than the SOY diet $(5.7 \mathrm{~g} / \mathrm{kg})$, which contributed to the greater reduction in enteric $\mathrm{CH}_{4}$ production in those diets (13-27 mg/d) compared to the SOY diet $(84 \mathrm{mg} / \mathrm{d})$. Apparent and true nutrient digestibilities were not affected by the addition of ground oilseeds. While $\mathrm{N}$ intake increased concomitant with crude protein increases in the diets, there were no additional effects on $\mathrm{N}$ flows. While supplementing a high-CT diet with any of the three oilseeds (canola, soybean, sunflower, or a mixture of the three oilseeds) reduced total $\mathrm{CH}_{4}$ emission without depressing nutrient digestibility, canola and mixes containing canola were most effective. Further research is needed in vivo to evaluate whether these results translate to greater feed efficiency and animal production.
\end{abstract}

Keywords: forage; methane; nutrient digestibility; oilseeds; tannin

\section{Introduction}

Greenhouse gases such as methane $\left(\mathrm{CH}_{4}\right)$ are well-established contributors to degradation of the ozone layer [1]. This has led to rising global temperatures and exacerbated climate change for the past several decades [2]. While there are multiple sources of greenhouse gas pollution, particularly from fossil fuels, livestock $\mathrm{CH}_{4}$ emissions have also drawn 
substantial attention from the general public [3]. Data from the past decade indicate that enteric $\mathrm{CH}_{4}$ production by ruminant livestock comprises more than $25 \%$ of all agricultural greenhouse gas sources [4]. Further data from the US and Australia indicated that beef cattle and dairy cows (Bos taurus L.) are the primary $\mathrm{CH}_{4}$-producing livestock species [5,6]. Therefore, addressing $\mathrm{CH}_{4}$ emissions by changing the dietary and nutritional profile of these ruminant livestock is of critical importance to reducing agriculture's contribution to global climate change.

Numerous feed additives and dietary supplements have been examined for the potential reduction in $\mathrm{CH}_{4}$ emissions in ruminants [7]. However, this reduction is often at the expense of animal performance or feed efficiency. A class of polyphenolic compounds known as condensed tannins (CT) exemplify this pattern of substantially reducing $\mathrm{CH}_{4}$ emissions [8]. Other benefits of CT include reduced risk of bloat and internal parasite infection $[9,10]$. However, forages containing high levels of CT $(>25 \mathrm{~g} / \mathrm{kg})$ have been shown to have detrimental effects on nutrient digestibility [11]. Condensed tannins are naturally produced by several leguminous forages, including sericea lespedeza (SL; Lespedeza cuneata (Dum. Cours.) G. Don), sainfoin (Onobrychis spp. Mill.), and birdsfoot trefoil (Lotus corniculatus L.), as defense from herbivory. There is also a wide range in the concentration of CT within many forage legumes, which can alter the efficacy of reducing $\mathrm{CH}_{4}$ emissions or affect feed digestibility [12]. Previous work found that diets containing 50\% of DM as SL (the highest CT of all forages evaluated) had the lowest $\mathrm{CH}_{4}$ emissions but also had the lowest DM, OM, NDF, and ADF digestibilities compared with legumes containing lower CT concentrations [11]. This exemplifies the need to develop ruminant diets with balanced CT concentrations to provide the maximum $\mathrm{CH}_{4}$ reduction while simultaneously minimizing impacts on digestibility [13].

Oilseeds such as soybean (Glycine max L.), canola (Brassica napus L.), and sunflower (Helianthus annuus L.) are high in lipid content, with over $80 \%$ of their energy reserves being in the form of fatty acids [14]. The crude fat (CF) of oilseeds via wet chemistry provides a measure of lipid content, which is the most likely contributor to reducing $\mathrm{CH}_{4}$ emissions and can modify milk fatty acid profiles in dairy cows [15]. For example, monounsaturated fatty acids (palmitoleic (16:1) and oleic (18:1)), polyunsaturated fatty acids (linoleic (18:2), linolenic (18:3)), and medium-chain fatty acids are toxic to the methanogenic bacteria in the rumen $[16,17]$. Recent work has also shown that lipid-encapsulated tannins from acacia shrubs (Acacia penninervis DC) significantly reduced enteric $\mathrm{CH}_{4}$ production at a similar rate to unencapsulated tannins, but NDF and ADF digestibilities were greater than in unencapsulated tannins [18].

Because oilseeds are primarily composed of lipids, they can be effective at reducing enteric $\mathrm{CH}_{4}$ emissions in small proportions $(<10 \%)$ of the diet. Soder et al. [19] found no reduction in nutrient digestibility when flaxseed, canola, or sunflower were fed in vitro at $10 \%$ of total DM to an herbage diet, but $\mathrm{CH}_{4}$ was not evaluated in that study. Beauchemin et al. [20] showed a significant reduction in $\mathrm{CH}_{4}$ production when sunflower, flaxseed, and canola were supplemented at 3.1 to $4.2 \%$ of diet DM to lactating dairy cows fed TMR. However, digestible dry matter (DM) intake was reduced by flax and sunflower, but there was no reduction in digestible DM intake with canola. Recent work with a similar oilseed, hemp (Canabis sativa L.), has also shown the efficacy of high-lipid seed meal in reducing enteric $\mathrm{CH}_{4}$ with less than $11 \mathrm{~mL} \mathrm{CH}_{4} / \mathrm{g}$ /day and organic matter digestibilities ranging from 30 to $40 \%$ [21].

While both CT and oilseeds have independently been effective at reducing enteric $\mathrm{CH}_{4}$ emissions in cattle, there has been little examination of their potential additive effects on $\mathrm{CH}_{4}$ emissions or ruminal fermentation. If fed in tandem with $\mathrm{CT}$, the properties of lipids found in oilseeds may reduce the negative effects of CT on the digestibility of consumed forages while providing greater reductions in enteric $\mathrm{CH}_{4}$ emission. However, this hypothesis has yet to be evaluated. Therefore, the objective of this study was to evaluate the efficacy of feeding ground oilseeds of three species with diets containing SL to reduce enteric $\mathrm{CH}_{4}$ emissions and minimize negative effects on diet digestibility. We hypothesized 
that oilseed species containing the greatest lipid content would exhibit similar reductions in $\mathrm{CH}_{4}$ emissions while having the least adverse impact on nutrient digestibility.

\section{Materials and Methods}

A rumen fluid donor cow was housed at the Pennsylvania State University Dairy Research Farm (University Park, PA, USA) and managed under Pennsylvania State University Institutional Animal Care and Use Committee guidelines (IACUC; protocol no. 46212).

\subsection{Site, Experimental Design, and Diets}

This study was conducted at the USDA-ARS Pasture Systems and Watershed Management Research Unit (University Park, PA, USA) from September to November 2016. The orchardgrass $(\mathrm{OCH})$ was grown and harvested from a 3 yr stand located at the Russell E. Larson Agricultural Research Center (Rock Springs, PA, USA; 40 40 $00^{\prime \prime}$ N, $77^{\circ} 56^{\prime} 24^{\prime \prime}$ W). Vegetative biomass was harvested in summer 2016, freeze-dried to preserve nutritional value, and ground in a Wiley Mill (Thomas Scientific, Swedesboro, NJ, USA) to pass a $2 \mathrm{~mm}$ mesh screen. The biomass of the SL cultivar 'AU Grazer' (Sims Brothers, Inc., Union Springs, AL, USA) was harvested in July 2015 from a 3 yr monoculture, grown at the University of Kentucky's Spindletop Research Farm (Lexington, KY; $30^{\circ} 7^{\prime} 40^{\prime \prime}$ N, 84 29 $39^{\prime \prime}$ W). The harvest of SL biomass occurred at the flowering stage, and material was freeze-dried and ground in a Wiley Mill to a $2 \mathrm{~mm}$ particle size. Oilseed crop seeds were from the following cultivars: 'Inspiration' canola (Rubisco Seeds, Philpot, KY, USA), 'Peredovic' sunflower (Hancock Seed Company, Dade City, FL, USA), and 'Stonewall' soybean (Hancock Seed Company, Dade City, FL, USA). Seeds were not freeze-dried but were ground to $2 \mathrm{~mm}$ fineness in a cyclone mill (UDY Corp., Fort Collins, CO, USA). The $2 \mathrm{~mm}$ fineness was selected to prevent oil particles from forming when grinding the oilseeds. Thus, all material (forage and oilseeds) were ground to this fineness. Ground whole seeds were used to maintain the fatty acid composition, compared to seed meals which have been extracted.

A $4 \times 4$ Latin square design was used to randomize four diets within each of four $10 \mathrm{~d}$ periods. Each diet comprised identical basal forages, with $45 \%$ OCH and $45 \%$ SL (high-CT legume), with the remaining $10 \%$ comprising one of three oilseed supplements as follows: $10 \%$ canola seed (CAN), 10\% soybean seed (SOY), 10\% sunflower seed (SUN), and an even $\operatorname{mix}(3.33 \%$ each) of canola, soybean, and sunflower (MIX).

\subsection{Continuous Culture System}

A four-unit single-flow continuous culture in vitro fermentation system (Applikon Biotechnology, B.V. Schidam, The Netherlands) was used to simulate rumen digestion. Details of this system can be found in Dillard et al. [22]. Fermentors were fed four times daily (20.5 g/feeding) at 07:30, 10:30, 14:00, and 19:00 h, with daily DM fed fixed at $82 \mathrm{~g} / \mathrm{d}$. The digesta retention time and buffer dilution rate were adjusted daily via regulation of effluent removal and buffer flow and were maintained at $24 \mathrm{~h}$ and $10 \% / \mathrm{h}$, respectively. Rumen fluid and digesta were collected from a fistulated, nonlactating, nonpregnant, 4-year-old Holstein cow (794 kg body weight) fed a diet of silage, hay, and grain (3:1 forageto-concentrate ratio, ad libitum). On the morning of $\mathrm{d} 1$ of each period, approximately two hours after feeding, $7 \mathrm{~L}$ of rumen fluid was collected from the donor cow using a hand pump and placed into plastic airtight containers that were pre-warmed to $39^{\circ} \mathrm{C}$. Solid rumen digesta (of the 3:1 forage-to-concentrate diet) was collected by hand from the ventral, central, and dorsal areas of the rumen. Within $30 \mathrm{~min}$ of collection, rumen fluid and solid digesta were transported back to the USDA-ARS lab to prepare for transfer into fermentor vessels. Fluid was first strained through four layers of cheesecloth and 1.5 L was poured into each of the four pre-warmed fermentor vessels. Each fermentor was then inoculated with $32 \mathrm{~g}$ of solid digesta. The flow of $\mathrm{CO}_{2}$ was initiated at $20 \mathrm{~mL} / \mathrm{min}$ for $1.5 \mathrm{~h}$ following inoculation to create anaerobic conditions in each vessel and then lowered to $1 \mathrm{~mL} / \mathrm{min}$ for the duration of the experimental period. 
Each $10 \mathrm{~d}$ period consisted of seven days of diet adaptation followed by three days of sampling. For each fermentor, daily effluent was removed, pumped into a $4 \mathrm{~L}$ storage container, and cooled to $4{ }^{\circ} \mathrm{C}$ to inhibit further microbial fermentation. The contents of these $4 \mathrm{~L}$ containers were weighed during days $1-7$ to calibrate effluent removal to approximately $4 \mathrm{~L} / \mathrm{d}$ and then discarded. At the 10:30 $\mathrm{h}$ feeding (second daily feeding) on days 8-10, daily effluent contents were weighed, mixed with a blender (model 38 LL52 Waring; Torrington, CT, USA), and then subsampled. First, $50 \mathrm{~mL}$ of effluent was strained through 8 layers of cheesecloth. Then, 2 containers containing $3 \mathrm{~mL}$ of $25 \% \mathrm{~m}$-phosphoric acid were each filled with $15 \mathrm{~mL}$ of strained effluent for determination of VFA [23] and $\mathrm{NH}_{3}-\mathrm{N}$ [24] concentrations. Finally, $1 \mathrm{~L} / \mathrm{d}$ of blended effluent was collected and composited across all three sampling days ( $3 \mathrm{~L}$ total) for assessment of effluent nutritive value parameters. Composited effluent samples were then freeze-dried, ground to pass through a $1 \mathrm{~mm}$ sieve, and stored in sealed plastic bags for later analyses.

\subsection{Methane Quantification}

During each $10 \mathrm{~d}$ period, $\mathrm{CH}_{4}$ measurements were taken at $10 \mathrm{~min}$ intervals on each fermentor vessel using a photoacoustic gas monitor (LumaSense Technologies Inc., Santa Clara, CA, USA) connected to a multiport sampler (CAI, Inc., Orange, CA, USA) that controlled the flow of gas from the headspace of each vessel. These readings resulted in six readings/fermentor/h, with a total of 2880 readings per fermentor over each $10 \mathrm{~d}$ period. Each 10 min cycle of the gas monitor required $140 \mathrm{~cm}^{3}$ of the $1500 \mathrm{~mL}$ of headspace gas in the vessel. Daily $\mathrm{CH}_{4}$ production was calculated with the following equation:

$$
\sum\left[\mathrm{CH}_{4} \text { volume }_{\mathrm{a}}-\mathrm{CH}_{4} \text { volume }_{\mathrm{b}}\right]
$$

where $\mathrm{CH}_{4}$ volume was defined as the headspace volume multiplied by the $\mathrm{CH}_{4}$ concentration, and $\mathrm{CH}_{4}$ volume ${ }_{b}$ was defined as the $\mathrm{CH}_{4}$ volume 10 min prior to measuring volume $_{\mathrm{a}}$, summed over each of the three $24 \mathrm{~h}$ sampling days.

\subsection{Nutrient Analyses}

Forage and seeds were analyzed via wet chemistry (Dairy One, Ithaca, NY, USA) for the following procedures: DM (method 930.15; [25]), CP (method 990.03; [25]), RDP (Cornell Streptomyces griseus enzymatic digestion; [26]), aNDF (Ankom Technology method 6), ADF [27], lignin [27], and CF (method 2003.05; [25]). Non-fibrous carbohydrate was calculated as

$$
\mathrm{g} / \mathrm{kg} \mathrm{NFC}=100-[\mathrm{CP}(\mathrm{g} / \mathrm{kg})+\mathrm{NDF}(\mathrm{g} / \mathrm{kg})+\mathrm{CF}(\mathrm{g} / \mathrm{kg})+\mathrm{ash}(\mathrm{g} / \mathrm{kg})]
$$

Total digestible nutrients were calculated from formulas derived from Weiss [28]. Forage and seed samples were sent to the Department of Plants, Soils, and Climate at Utah State University (Logan, UT, USA), where CT concentrations were quantified using a butanol-HCl-iron assay [29].

Effluent samples were analyzed for DM and OM (methods 930.15 and 942.05; [25]), $\mathrm{CP}$ (micro-Kjeldahl digestion using $75 \mathrm{~mL}$ calibrated tubes with $\mathrm{CuSO}_{4}$ catalyst; method 976.06; [25]), and aNDF [27] using $\alpha$-amylase and sodium sulfite (inclusive of ash). Concentrations of total and individual VFA were determined using gas chromatography (Varian 330 Gas Chromatograph (FID Detector), Varian 4290 Integrator; Supelco, 1975, modified to use an 80/120 Carbopack B-DA/4\% Carbowax $20 \mathrm{M}$ column) at the Rumen Fermentation Profiling Laboratory at West Virginia University (Morgantown, WV, USA).

\subsection{Statistical Analyses}

Data were analyzed as a $4 \times 4$ Latin square, using PROC GLIMMIX in SAS 9.4 (SAS Institute, Cary, NC, USA). Repeated measures with an autoregressive covariance structure were used for the response variables $\mathrm{CH}_{4}$ concentration, VFA concentrations, and fermentor $\mathrm{pH}$ levels, as these values were recorded daily over the three sampling days. For these 
variables, period and diet were considered fixed effects, while fermentor and sampling day were considered random effects. The following model was used for these variables:

$$
Y_{i j k l}=\mu+P_{i}+F_{j}+D_{k}+P D_{i k}+T_{l}+P T_{i l}+\varepsilon_{(i j k l)}
$$

where $\mu$ = population mean, $P_{i}=$ mean effects of the $i$ th period, $F_{j}=$ mean effects of the $j$ th fermentor, $D_{k}=$ mean effects of the $k$ th sampling day, $T_{l}=$ mean effects of the $l$ th diet, and $\varepsilon_{(i j k l)}=$ experimental error. A second model was used to assess digestibility and $\mathrm{N}$ metabolism data, without repeated measures, as values were only assessed on a per-period basis. Again, period at diet was a fixed effect, while fermentor was considered a random effect:

$$
Y_{i j k l}=\mu+P_{i}+F_{j}+T_{k}+P T_{i k}+\varepsilon_{(i j k)}
$$

where $\mu$ = population mean, $P_{i}=$ mean effects of the $i$ th period, $F_{j}=$ mean effects of the $j$ th fermentor, $T_{k}=$ mean effects of the $k$ th diet, and $\varepsilon_{(i j k)}=$ experimental error.

For all statistical analyses, an alpha level of $\alpha=0.05$ was used to determine significant differences, while trends were established at an alpha level of $0.10>\alpha>0.05$. After conducting analysis of variance, no period $\times$ diet interactions were found for any variables tested; therefore, only main effects are presented.

\section{Results}

\subsection{Diet Composition and Digestibilities}

The chemical compositions of the ingredients and diets are presented in Table 1. Statistical comparison of diets was not conducted because the nutrient composition of diets was based on pooled samples. The CT concentration of the SL forage was $149 \mathrm{~g} / \mathrm{kg} \mathrm{DM}$, compared to $3.7 \mathrm{~g} / \mathrm{kg} \mathrm{DM}$ for $\mathrm{OCH}$, and less than $1 \mathrm{~g} / \mathrm{kg} \mathrm{DM}$ for the ground canola, soybean, and sunflower oilseeds. As all diets contained the same amount of SL, final CT concentrations were identical among diets $(68.9 \mathrm{~g} / \mathrm{kg}$ DM). Crude fat concentrations of canola and sunflower were approximately twice the numeric value of soybean. This resulted in the SOY diet having only $5.7 \% \mathrm{CF}$, compared to $7-8 \% \mathrm{CF}$ in the CAN, SUN, and MIX diets. While the ground soybean seed used to formulate the diets was greater in CP and RDP and had lower aNDF, ADF, and lignin than canola or sunflower, there were no distinct numerical trends observed among the final diets for any of the protein or fiber parameters. This was attributed to these components comprising only $10 \%$ of each diet.

\begin{tabular}{|c|c|c|c|c|c|c|c|c|c|c|}
\hline \multirow[b]{2}{*}{ Item } & \multirow[b]{2}{*}{ Unit } & \multicolumn{5}{|c|}{ Forage } & \multicolumn{4}{|c|}{ Diets $^{1}$} \\
\hline & & Orchardgrass & $\begin{array}{c}\text { Sericea } \\
\text { Lespedeza }\end{array}$ & Canola & Soybean & Sunflower & CAN & SOY & SUN & MIX \\
\hline $\mathrm{CP}$ & $\mathrm{g} / \mathrm{kg} \mathrm{DM}$ & 348 & 178 & 246 & 406 & 139 & 261 & 277 & 251 & 263 \\
\hline RDP & $\mathrm{g} / \mathrm{kg} \mathrm{CP}$ & 810 & 323 & 651 & 807 & 750 & 574 & 589 & 584 & 581 \\
\hline aNDF & $\mathrm{g} / \mathrm{kg}$ DM & 412 & 460 & 416 & 172 & 283 & 434 & 410 & 421 & 421 \\
\hline ADF & $\mathrm{g} / \mathrm{kg} \mathrm{DM}$ & 222 & 324 & 290 & $15 \overline{3}$ & 243 & 275 & 261 & 270 & 268 \\
\hline Lignin & $\mathrm{g} / \mathrm{kg} \mathrm{DM}$ & 65 & 100 & 78 & 22 & 94 & 82 & 76 & 84 & 81 \\
\hline $\mathrm{NFC}^{2}$ & $\mathrm{~g} / \mathrm{kg} \mathrm{DM}$ & 118 & 271 & - & 154 & 139 & 175 & 190 & 189 & 175 \\
\hline $\mathrm{NE}_{\mathrm{L}}$ & Mcal/kg DM & 1.5 & 1.3 & 3.6 & 3.2 & 2.6 & 1.7 & 1.6 & 1.5 & 1.6 \\
\hline $\begin{array}{l}\text { Crude } \\
\text { Fat }\end{array}$ & $\mathrm{g} / \mathrm{kg} \mathrm{DM}$ & 50 & 29 & 437 & 210 & 404 & 79 & 57 & 76 & 70 \\
\hline $\mathrm{CT}^{3}$ & $\mathrm{~g} / \mathrm{kg} \mathrm{DM}$ & 3.7 & 149.2 & 0.8 & 0.3 & 0.3 & 68.9 & 68.9 & 68.9 & 68.9 \\
\hline
\end{tabular}

Table 1. Chemical compositions of ingredients and diets fed during continuous culture fermentation.

${ }^{1}$ All diets comprised $45 \%$ orchardgrass and $45 \%$ sericea lespedeza. The remaining $10 \%$ was as follows: CAN $=10 \%$ ground canola seed, $\mathrm{SOY}=10 \%$ ground soybean seed, $\mathrm{SUN}=10 \%$ ground sunflower seed, and MIX $=3.33 \%$ ground canola, $3.33 \%$ ground soybean, and $3.33 \%$ ground sunflower seed. ${ }^{2}$ Calculated as NFC $(\%)=100-$ $[\mathrm{CP}(\%)+$ aNDF $(\%)+$ crude fat $(\%)+$ ash $(\%)] .{ }^{3}$ CT: condensed tannins.

No differences were observed $(p>0.10)$ in either apparent or true DM and OM digestibilities among oilseed diets (Table 2). Additionally, apparent aNDF and ADF digestibilities were similar between diets $(p>0.10)$. 
Table 2. Nutrient digestibilities of four high-condensed-tannin herbage diets containing ground canola, soybean, sunflower seed, or a mix of the three oilseeds during continuous culture fermentation.

\begin{tabular}{|c|c|c|c|c|c|c|}
\hline \multirow{2}{*}{ Parameter } & \multicolumn{4}{|c|}{ Diet $^{1}$} & \multirow{2}{*}{ SEM } & \multirow{2}{*}{$p$-Value } \\
\hline & CAN & SOY & SUN & MIX & & \\
\hline \multicolumn{7}{|l|}{ Apparent } \\
\hline \multicolumn{7}{|l|}{ Digestibility } \\
\hline $\mathrm{OM}$ & 0.39 & 0.41 & 0.40 & 0.37 & 0.044 & $>0.10$ \\
\hline $\mathrm{DM}$ & 0.39 & 0.42 & 0.41 & 0.39 & 0.033 & $>0.10$ \\
\hline aNDF & 0.52 & 0.60 & 0.453 & 0.54 & 0.032 & $>0.10$ \\
\hline $\mathrm{ADF}$ & 0.31 & 0.52 & 0.37 & 0.43 & 0.067 & $>0.10$ \\
\hline \multicolumn{7}{|c|}{ True Digestibility } \\
\hline $\mathrm{OM}$ & 0.81 & 0.81 & 0.78 & 0.84 & 0.039 & $>0.10$ \\
\hline $\mathrm{DM}$ & 0.65 & 0.67 & 0.63 & 0.68 & 0.032 & $>0.10$ \\
\hline
\end{tabular}

${ }^{1}$ All diets comprised $45 \%$ orchardgrass and $45 \%$ sericea lespedeza. The remaining $10 \%$ was as follows: CAN $=10 \%$ ground canola, $\mathrm{SOY}=10 \%$ ground soybean, $\mathrm{SUN}=10 \%$ ground sunflower, and MIX $=3.33 \%$ ground canola, $3.33 \%$ ground soybean, and $3.33 \%$ ground sunflower seed.

\subsection{Methane Production, VFAs, and $\mathrm{pH}$}

Total daily $\mathrm{CH}_{4}$ production was the lowest $(p<0.001)$ in the MIX and CAN diets, intermediate in the SUN diet, and the highest in the SOY diet $(p<0.001$; Table 3). Production of $\mathrm{CH}_{4}$ per gram of OM and aNDF was greater $(p=0.01)$ for the SOY diet, compared to all three other diets. These effects were magnified when the amount of $\mathrm{CH}_{4}$ produced per gram of digestible OM and aNDF was examined. Both parameters resulted in the MIX, CAN, and SUN diets having less $\mathrm{CH}_{4}$ produced per gram of digestible $\mathrm{OM}(p=0.01)$ or aNDF $(p=0.02)$ than the SOY diet.

The SOY diet had the greatest $(p<0.001)$ total VFA concentration (Table 3). Molar proportions of acetate were the greatest $(p<0.001)$ for SOY and the lowest for CAN and MIX. Molar proportions of propionate were the greatest $(p=0.001)$ for the CAN and MIX diets and the lowest $(p=0.001)$ for the SOY diet. Butyrate proportions were the greatest $(p<0.01)$ in the MIX diet. The CAN and SOY diets had the greatest $(p=0.01)$ proportions of isobutyrate, while the MIX diet had the lowest. Molar proportions of valerate were the greatest $(p<0.001)$ for the CAN and MIX diets and the lowest for the SOY diet. The CAN and MIX diets had the greatest $(p<0.001)$ proportions of valerate. Isovalerate was undetectable for all diets (data not shown). The CAN and MIX diets had the lowest $(p<0.001)$ ratios of acetate/propionate $(\mathrm{A} / \mathrm{P})$, acetate and butyrate/propionate $(\mathrm{A}+\mathrm{B} / \mathrm{P})$, and acetate and butyrate/propionate and valerate $(\mathrm{A}+\mathrm{B} / \mathrm{P}+\mathrm{V})$, while the SOY diet had the greatest $(p<0.001)$ ratio in all three parameters.

The SOY diet had the lowest $(p<0.001)$ mean, maximum, and minimum fermentor $\mathrm{pH}$ (Table 3). The MIX diet had the greatest $(p<0.001)$ mean and minimum $\mathrm{pH}$, while the MIX, CAN, and SUN diets had the greatest maximum $\mathrm{pH}$ and minimum $\mathrm{pH}$ (Table 3).

The SOY diet had the greatest N intake, followed sequentially by MIX, CAN, and SUN $(p<0.001$; Table 3). No other parameters of $\mathrm{N}$ metabolism were affected $(p>0.10)$ by the oilseeds added to the high-CT basal diet. 
Table 3. Methane $\left(\mathrm{CH}_{4}\right)$ output, volatile fatty acid (VFA) production, and fermentor $\mathrm{pH}$ of four high-condensed-tannin herbage diets containing ground canola, soybean, sunflower seed, or a mix of the three oilseeds during continuous culture fermentation. Molar proportions of specific VFAs are given as mols per 100 mols of total VFAs.

\begin{tabular}{|c|c|c|c|c|c|c|c|}
\hline \multirow[b]{2}{*}{ Item } & \multirow[b]{2}{*}{ Unit } & \multicolumn{4}{|c|}{ Diet $^{1}$} & \multirow[b]{2}{*}{ SEM } & \multirow[b]{2}{*}{$p$-Value } \\
\hline & & CAN & SOY & SUN & MIX & & \\
\hline \multicolumn{8}{|l|}{$\mathrm{CH}_{4}$ production } \\
\hline Total $\mathrm{CH}_{4}$ & $\mathrm{mg} / \mathrm{d}$ & $17.9^{\mathrm{c}}$ & $84.3^{\mathrm{a}}$ & $27.4^{\mathrm{b}}$ & $13.4^{\mathrm{c}}$ & 4.41 & 0.01 \\
\hline $\mathrm{CH}_{4} / \mathrm{g} \mathrm{OM}$ & $\mathrm{mg} / \mathrm{g}$ & $0.2^{\mathrm{b}}$ & $1.1^{\mathrm{a}}$ & $0.4^{\mathrm{b}}$ & $0.2^{\mathrm{b}}$ & 0.79 & 0.01 \\
\hline $\mathrm{CH}_{4} / \mathrm{g}$ aNDF & $\mathrm{mg} / \mathrm{g}$ & $0.5^{b}$ & $2.5^{\mathrm{a}}$ & $0.8^{b}$ & $0.4^{b}$ & 1.84 & 0.01 \\
\hline $\mathrm{CH}_{4} / \mathrm{g}$ digestible $\mathrm{OM}$ & $\mathrm{mg} / \mathrm{g}$ & $0.4^{b}$ & $1.6^{\mathrm{a}}$ & $0.6^{\mathrm{b}}$ & $0.3^{b}$ & 1.02 & 0.01 \\
\hline \multicolumn{8}{|l|}{ VFA } \\
\hline Total & $\mathrm{mmol} / \mathrm{L}$ & $38.33^{b}$ & $46.04^{\mathrm{a}}$ & $37.52^{b}$ & $38.73^{b}$ & 1.056 & $<0.001$ \\
\hline Acetate (A) & $\mathrm{mol} / 100 \mathrm{~mol}$ & $66.7^{c}$ & $68.1^{\mathrm{a}}$ & $67.3^{\mathrm{b}}$ & $66.4^{\mathrm{c}}$ & 0.20 & $<0.001$ \\
\hline Propionate $(\mathrm{P})$ & $\mathrm{mol} / 100 \mathrm{~mol}$ & $22.8^{\mathrm{a}}$ & $21.5^{\mathrm{c}}$ & $22.3^{b}$ & $22.8^{\mathrm{a}}$ & 0.18 & $<0.001$ \\
\hline Butyrate (B) & $\mathrm{mol} / 100 \mathrm{~mol}$ & $8.7^{\mathrm{b}}$ & $8.7^{\mathrm{b}}$ & $8.8^{b}$ & $9.1^{\mathrm{a}}$ & 0.12 & 0.01 \\
\hline Isobutyrate & $\mathrm{mol} / 100 \mathrm{~mol}$ & $0.3^{\mathrm{a}}$ & $0.4^{\mathrm{a}}$ & $0.3^{b}$ & $0.2^{\mathrm{c}}$ & 0.038 & 0.01 \\
\hline Valerate (V) & $\mathrm{mol} / 100 \mathrm{~mol}$ & $1.5^{\mathrm{a}}$ & $1.3^{\mathrm{c}}$ & $1.4^{\mathrm{b}}$ & $1.5^{\mathrm{a}}$ & 0.029 & $<0.001$ \\
\hline $\mathrm{A} / \mathrm{P}$ & $\mathrm{mol} / 100 \mathrm{~mol}$ & $2.93^{c}$ & $3.18^{a}$ & $3.02^{b}$ & $2.92^{\mathrm{c}}$ & 0.032 & $<0.001$ \\
\hline$(\mathrm{A}+\mathrm{B}) / \mathrm{P}$ & $\mathrm{mol} / 100 \mathrm{~mol}$ & $3.31^{\mathrm{c}}$ & $3.59^{\mathrm{a}}$ & $3.42^{b}$ & $3.32^{\mathrm{c}}$ & 0.036 & $<0.001$ \\
\hline \multicolumn{8}{|l|}{$\mathrm{pH}$} \\
\hline Mean $\mathrm{pH}$ & & $6.96^{\mathrm{b}}$ & $6.83^{c}$ & $6.95^{\mathrm{b}}$ & $7.01^{\mathrm{a}}$ & 0.022 & $<0.001$ \\
\hline Max pH & & $7.50^{\mathrm{a}}$ & $7.33^{b}$ & $7.52^{\mathrm{a}}$ & $7.53^{\mathrm{a}}$ & 0.035 & $<0.001$ \\
\hline Min $\mathrm{pH}$ & & $6.70^{b}$ & $6.58^{c}$ & $6.67^{b}$ & $6.77^{a}$ & 0.015 & $<0.001$ \\
\hline \multicolumn{8}{|l|}{ Nitrogen metabolism } \\
\hline $\mathrm{N}$ intake & $\mathrm{g} / \mathrm{d}$ & $4.21^{\mathrm{c}}$ & $4.42^{\mathrm{a}}$ & $4.07^{\mathrm{d}}$ & $4.24^{\mathrm{b}}$ & 0.01 & $<0.001$ \\
\hline $\mathrm{NH}_{3}-\mathrm{N}$ & $\mathrm{mg} / \mathrm{dL}$ & 17.3 & 18.4 & 17.4 & 16.6 & 1.13 & $>0.10$ \\
\hline \multicolumn{8}{|l|}{$\mathrm{N}$ flows } \\
\hline Total N & $\mathrm{g} / \mathrm{d}$ & 2.6 & 2.4 & 2.5 & 2.3 & 0.26 & $>0.10$ \\
\hline $\mathrm{NH}_{3}-\mathrm{N}$ & $\mathrm{g} / \mathrm{d}$ & 0.74 & 0.78 & 0.74 & 0.71 & 0.034 & $>0.10$ \\
\hline Non- $\mathrm{NH}_{3}-\mathrm{N}$ & $\mathrm{g} / \mathrm{d}$ & 1.8 & 1.6 & 1.7 & 1.6 & 0.28 & $>0.10$ \\
\hline
\end{tabular}

\section{Discussion}

\subsection{Importance of Diet Composition and Digestibilities}

The observed proportions of CF for individual oilseeds (Table 1) followed those established by Liu et al. (2016) [30]. This resulted in the SOY diet having only $57 \mathrm{~g} \mathrm{CF} / \mathrm{kg}$ DM, compared to 70-79 $\mathrm{g} \mathrm{CF} / \mathrm{kg}$ DM in the CAN, SUN, and MIX diets. While the ground soybean used to formulate the diets was greater in CP and RDP and had lower aNDF, ADF, and lignin than canola or sunflower, there were no distinct numerical trends observed among the final diets for any of the protein or fiber parameters. This was attributed to the oilseed supplements comprising only $10 \%$ of each diet.

For this study, SL was the only appreciable source of CT in the components of any diet. Thus, the addition of the oilseeds, alone, did not affect the digestibilities of a high-CT diet (Table 2) as the total CT concentration in the diet was numerically similar across all diets. Sericea lespedeza is known to have one of the highest concentrations of CT among forage legumes [31], which our work supports (149.2 g CT/kg). In another continuous culture fermentor study, Roca-Fernández et al. [11] digested legumes (alfalfa (Medicago sativa L.), birdsfoot trefoil (Lotus corniculatus L.), crown vetch (Securigera varia L.), and SL) that ranged from 2.3 to $148 \mathrm{~g} / \mathrm{kg}$ of DM in CT and found that as the CT in the diet increased, $\mathrm{CH}_{4}$ decreased, but there was also a corresponding decrease in nutrient digestibility. Work 
with lambs fed acacia (Acacia cyanophylla Lindl.) leaves (approximately $50 \mathrm{~g} \mathrm{CT} / \mathrm{kg}$ ) supplemented with soybean meal nearly doubled average daily gains while maintaining CP digestibilities in excess of 0.70 [32]. Therefore, oilseeds could potentially improve the digestibility of a diet with a lower concentration of CT than the SL diet used in this study. However, this might necessitate different processing of the oilseeds (i.e., using seed meal or concentrated oil extracts instead of ground seeds).

\subsection{Effects on Enteric Methane Production, VFAs, Fermentor $p H$, and N Metabolism}

The reductions in $\mathrm{CH}_{4}$ production provided by the high-CT forage are even greater than those reported by Roca-Fernández et al. [11] when oilseed supplements were added to the diet (Table 3). In the present study, soybean was not as effective in reducing $\mathrm{CH}_{4}$ production as canola, sunflower, or a mixture of all three species; the SOY diet produced three to four times the amount of $\mathrm{CH}_{4}(\sim 84 \mathrm{mg} / \mathrm{d})$ as the CAN, SUN, and MIX diets. This was likely due to the lower concentration of CF present in the ground soybean used in the SOY diet, compared to the concentrations in the ground canola and sunflower seed. It is important to note that soybean is the most readily available oilseed available for animal feed supplementation and is commonly used as a protein source [33]. Producers interested in lowering $\mathrm{CH}_{4}$ emissions from their beef cattle or dairy cows should consider either canola, sunflower, or oilseed mixes. This will assist in minimizing the $\mathrm{CH}_{4}$ impact of farming systems and contribute to reduced greenhouse gas emissions. However, these other sources are likely more expensive than soybeans, and not as readily available; therefore, farmers would need an economic incentive to incorporate these supplements into herd rations.

The crude fat concentration in the diet has been previously shown to reduce enteric $\mathrm{CH}_{4}$ emissions in ruminants [34]. There was a trend of $\mathrm{CH}_{4}$ production being negatively correlated with CF (Pearson correlation coefficient $=-0.81, p=0.08$, data not shown). The greater $\mathrm{CH}_{4}$ production with the SOY diet could be attributed to the lower proportion of unsaturated fatty acids in soybean ( 85\%; [14]), compared to that of canola ( 92\%; [35]). Unsaturated fatty acids were found to reduce the production of $\mathrm{CH}_{4}$ in ruminants as far back as the 1960s, with an increasing concentration of these fatty acids causing further reductions in $\mathrm{CH}_{4}$ [36]. This was attributed to unsaturated fatty acids competing for $\mathrm{H}^{+}$ ions in the rumen during hydrogenation, which would otherwise be used to form $\mathrm{CH}_{4}$ [37]. While more recent work has focused on the addition of concentrated soybean oil or canola oil to rations, our work suggests that a reduction in $\mathrm{CH}_{4}$ in the $\mathrm{CAN}$, SUN, and MIX diets was still imparted when these oilseeds were simply fed as ground seed. When oilseeds are combined with $\mathrm{CT}$ in the diet, these results indicate that $\mathrm{CH}_{4}$ emissions from ruminal fermentation can be significantly reduced, i.e., $<30 \mathrm{mg} \mathrm{CH}_{4} / \mathrm{d}$ (CAN, SUN, or MIX diets) vs. $>200 \mathrm{mg} \mathrm{CH}_{4} / \mathrm{d}$ (50\% orchardgrass, $50 \%$ alfalfa diet) when no CT or ground oilseeds are fed [11].

The VFA results (Table 3) are important to note for several reasons. First, the lower total VFA concentrations found in the CAN, SUN, and MIX diets could be attributed to the greater concentration of CF in those diets $(7-8 \mathrm{~g} / \mathrm{kg})$, compared to the SOY diet $(5.7 \mathrm{~g} / \mathrm{kg})$. This suggests that greater amounts of CF may have a negative relation to VFA production, both on an individual and total VFA basis. Work from the 1960s and 1970s found either (a) no effect of feeding a greater fat content on VFA production [38,39] or (b) conflicting results to our findings, i.e., increased acetate, but decreased propionate, in high-fat diets [40]. However, these older trials used extracted and pure seed oil, molasses, or other high-fat plant products. More recent work from Paula et al. [41] found that some individual VFAs were decreased with canola meal. However, these effects were not as consistent as the results of the present study, likely due to the extraction process removing much of the fat content. A recent in vitro study found a significant decrease in VFA production in response to increasing $\mathrm{CT}$ in forage diets containing legumes differing in $\mathrm{CT}$, the highest of which was a 50:50 OCH/SL diet [11]. The results of the current study show that the addition of $10 \%$ oilseeds that contain high CF concentrations (CAN, SUN, or MIX vs. SOY diets) to 45:45 OCH/SL diets might also be provoking significant declines in ruminal VFA 
production. Depending on what VFAs are affected, this may cause detrimental effects on milk production or milk quality components for dairy or reduce live-weight gains in beef production.

The fermentor $\mathrm{pH}$ data (Table 3) were similar to those from a previous study by Kowalczyk et al. [42] where sequential rates of tallow (high in lipid concentration) were added as supplements to ruminant diets. However, such small differences likely would not be biologically significant [43]. It should be noted that the high-CT diets in the present study had a mean $\mathrm{pH}$ that was slightly more alkaline (6.9-7.0) than normal forage diets ( 6.5-6.7) [44]. This accounts for the increased acetate production compared to propionate that was observed across all four diets. However, the small biological difference in $\mathrm{pH}$ likely would not be the cause for the differences in the VFA concentration among diets, as all $\mathrm{pH}$ values were well within the normal range for optimal rumen function [45].

The addition of ground oilseeds to the basal diet had no impact on the $\mathrm{N}$ flows (Table 3). However, the greater $\mathrm{CP}$ concentrations in certain oilseed species, e.g., soybean, did affect the amount of $\mathrm{N}$ present in each diet. This may be due to soybean providing a high-quality protein source of $\mathrm{N}$ to enhance the supply of CP and RDP from preformed AA and peptides in ruminal fermentation [8]. The ground soybean used in this in vitro work had less CP than normal soybean crops, $40 \%$ compared to $50-55 \%$ [46], likely due to Stonewall being an older, public release cultivar [47] that has not been selected for a greater $\mathrm{CP}$ concentration. If a different source of ground soybean was used for this study, it is likely that $\mathrm{N}$ flows in our in vitro system would have differed between diets, which is supported by the findings of [48] and research conducted by [49]. Another potential reason for the minimal effect of oilseeds was that they comprised only $10 \%$ of the diet. This limited the differences in dietary $\mathrm{CP}$ that were in each diet, because $\mathrm{OCH}$ and SL were the predominant components (45\% each) of the basal diets. Based on conclusions from Roca-Fernández et al. [11], it is likely that altering the source of CT would have more effect on $\mathrm{N}$ metabolism and flows, rather than which ground oilseed was added to the diet.

\section{Conclusions}

The addition of the oilseeds canola, sunflower, and a mixture of canola, sunflower, and soybean to an herbage diet high in $\mathrm{CT}$ reduced $\mathrm{CH}_{4}$ production compared to the addition of only soybean. This was attributed to the greater $\mathrm{CF}$ concentrations found in canola and sunflower compared to soybean, which equated to greater ruminal fatty acid concentrations that are antagonistic to enteric methanogenesis. At the same time, nutrient digestibility was not depressed, suggesting that animal performance may not be impaired. Total VFA production was, however, notably reduced in the CAN, SUN, and MIX diets, which was also attributed to the greater CF present in those diets and may negatively impact milk production, milk components, and live-weight gain. Future work to assess different levels, as well as different combinations, of oilseeds supplemented to high-CT diets on ruminal fermentation, $\mathrm{CH}_{4}$ production, and animal performance is needed.

Author Contributions: Conceptualization, A.I.R.-F., S.L.D. and K.J.S.; methodology, A.I.R.-F., S.L.D. and K.J.S.; validation, A.I.R.-F., S.L.D., E.D.B. and K.J.S.; formal analysis, E.D.B. and A.I.R.-F.; investigation, A.I.R.-F., S.L.D.; resources, K.J.S.; data curation, A.I.R.-F., S.L.D., E.D.B.; writing—original draft preparation, E.D.B., A.I.R.-F., S.L.D. and K.J.S.; writing-review and editing, E.D.B., A.I.R.-F., S.L.D. and K.J.S.; visualization, A.I.R.-F., S.L.D. and K.J.S.; supervision, K.J.S.; project administration, K.J.S.; funding acquisition, A.I.R.-F., S.L.D. and K.J.S. All authors have read and agreed to the published version of the manuscript.

Funding: This work was partially funded by USDA-NIFA-OREI (Project Number: 8070-21000-008-16) and Xunta de Galicia-Plan 12 C-Modality A (Project Number: ED481B-2014/021-0). USDA is an equal opportunity provider and employer.

Institutional Review Board Statement: The animal protocol used in this study was approved by the Pennsylvania State University Institutional Animal Care and Use Committee guidelines (IACUC; protocol no. 46212). 
Informed Consent Statement: Not applicable.

Data Availability Statement: Data will be made publicly available via Dryad Digital Repository within 30 months of publication per USDA-ARS guidelines.

Acknowledgments: The authors would like to thank C. Dell, M. Rubano, J. Everhart, R. Stout, and R. Tillman (USDA-ARS); J. MacAdam (Utah State University); and J. Dillon (Pennsylvania State University), for their laboratory expertise and time contributed to the project.

Conflicts of Interest: The authors declare no conflict of interest.

\begin{abstract}
Abbreviations
CAN: $10 \%$ canola diet; $\mathrm{CF}$, crude fat; $\mathrm{CH}_{4}$, methane; $\mathrm{CT}$, condensed tannins; IACUC, Institutional Animal Care and Use Committee; MIX, 10\% mixture of canola, soybean, and sunflower diet; $\mathrm{OCH}$, orchardgrass; SL, sericea lespedeza; SOY, $10 \%$ soybean diet; SUN, $10 \%$ sunflower diet.
\end{abstract}

\title{
References
}

1. Khan, M.Y.; Khan, F.; Haque, N. Global warming and stratospheric ozone layer depletion by greenhouse gases with special reference to methane production from Indian livestock. Anim. Nutr. Feed Technol. 2011, 1, 79-96.

2. West, J.J.; Fiore, A.M. Management of Tropospheric Ozone by Reducing Methane Emissions. Environ. Sci. Technol. 2005, 39, 4685-4691. [CrossRef] [PubMed]

3. Yusuf, R.O.; Noor, Z.Z.; Abba, A.H.; Hassan, M.A.A.; Din, M.F.M. Greenhouse gas emissions: Quantifying me-thane emissions from livestock. Am. J. Eng. Appl. Sci. 2012, 5, 1-8.

4. Archibeque, S.; Haugen-Kozyra, K.; Johnson, K.; Kebreab, E.; Powers-Schilling, W. Near-Term Options for Reducing Greenhouse Gas Emissions from Livestock Systems in the United States: Beef, Dairy, and Swine Production Systems; Nicholas Institute for Environmental Policy Solutions, Duke University: Durham, NC, USA, 2012.

5. Key, N.; Sneeringer, S. Climate change policy and the adoption of methane digesters on livestock operations. Econ. Res. Serv. USDA 2011. [CrossRef]

6. Rochfort, S.; Parker, A.; Dunshea, F.R. Plant bioactives for ruminant health and productivity. Phytochemistry 2008, 69, $299-322$. [CrossRef]

7. Boadi, D.; Benchaar, C.; Chiquette, J.; Massé, D. Mitigation strategies to reduce enteric methane emissions from dairy cows: Update review. Can. J. Anim. Sci. 2004, 84, 319-335. [CrossRef]

8. Cappucci, A.; Mantino, A.; Buccioni, A.; Casarosa, L.; Conte, G.; Serra, A.; Mannelli, F.; Luciano, G.; Foggi, G.; Mele, M. Diets supplemented with condensed and hydrolysable tannins affected rumen fatty acid profile and plasmalogen lipids, ammonia and methane production in an in vitro study. Ital. J. Anim. Sci. 2021, 20, 935-946. [CrossRef]

9. Athanasiadou, S.; Kyriazakis, I.; Jackson, F.; Coop, R.L. Direct anthelmintic effects of condensed tannins towards different gastrointestinal nematodes of sheep: In vitro and in vivo studies. Veter. Parasitol. 2001, 99, 205-219. [CrossRef]

10. Min, B.R.; Pinchak, W.E.; Anderson, R.C.; Fulford, J.D.; Puchala, R. Effects of condensed tannins supplementation level on weight gain and in vitro and in vivo bloat precursors in steers grazing winter wheat1. J. Anim. Sci. 2006, 84, 2546-2554. [CrossRef]

11. Roca-Fernández, A.I.; Dillard, S.L.; Soder, K.J. Ruminal fermentation and enteric methane production of legumes containing condensed tannins fed in continuous culture. J. Dairy Sci. 2020, 103, 7028-7038. [CrossRef]

12. Li, Y.; Iwaasa, A.D.; Wang, Y.; Jin, L.; Han, G.; Zhao, M. Condensed tannins concentration of selected prairie legume forages as affected by phenological stages during two consecutive growth seasons in western Canada. Can. J. Plant Sci. 2014, 94, 817-826. [CrossRef]

13. Naumann, H.D.; Tedeschi, L.O.; Zeller, W.E.; Huntley, N.F. The role of condensed tannins in ruminant animal production: Advances, limitations and future directions. Rev. Bras. Zootec. 2017, 46, 929-949. [CrossRef]

14. Bateman Ii, H.G.; Jenkins, T.C. Influence of Soybean Oil in High Fiber Diets Fed to Nonlactating Cows on Ruminal Unsaturated Fatty Acids and Nutrient Digestibility. J. Dairy Sci. 1998, 81, 2451-2458. [CrossRef]

15. Kliem, K.E.; Humphries, D.J.; Kirton, P.; Givens, D.I.; Reynolds, C.K. Differential effects of oilseed supplements on methane production and milk fatty acid concentrations in dairy cows. Animals 2019, 13, 309-317. [CrossRef]

16. Eugène, M.; Massé, D.; Chiquette, J.; Benchaar, C. Meta-analysis on the effects of lipid supplementation on methane production in lactating dairy cows. Can. J. Anim. Sci. 2008, 88, 331-337. [CrossRef]

17. Rasmussen, J.; Harrison, A. The Benefits of Supplementary Fat in Feed Rations for Ruminants with Particular Focus on Reducing Levels of Methane Production. ISRN Veter-Sci. 2011, 2011, 613172. [CrossRef] [PubMed]

18. Adejoro, F.A.; Hassen, A.; Akanmu, A.M. Effect of lipid-encapsulated acacia tannin extract on feed intake, nutrient digestibility, and methane emission in sheep. Animals 2019, 9, 863. [CrossRef]

19. Soder, K.J.; Brito, A.F.; Rubano, M.D. Short communication: Effect of oilseed supplementation of an herbage diet on ruminal fermentation in continuous culture. J. Dairy Sci. 2013, 96, 2551-2556. [CrossRef] [PubMed] 
20. Beauchemin, K.A.; McGinn, S.M.; Benchaar, C.; Holtshausen, L. Crushed sunflower, flax, or canola seeds in lactating dairy cow diets: Effects on methane production, rumen fermentation, and milk production. J. Dairy Sci. 2009, 92, 2118-2127. [CrossRef]

21. Vastolo, A.; Calabrò, S.; Pacifico, S.; Koura, B.I.; Cutrignelli, M.I. Chemical and nutritional characteristics of Cannabis sativa L. co-products. J. Anim. Physiol. Anim. Nutr. 2021, 105, 1-9. [CrossRef]

22. Dillard, S.L.; Roca-Fernández, A.I.; Rubano, M.D.; Soder, K.J. Evaluation of a single-flow continuous culture fermenter system for determination of ruminal fermentation and enteric methane production. J. Anim. Physiol. Anim. Nutr. 2019, 103, 1313-1324. [CrossRef] [PubMed]

23. Erwin, E.S.; Marco, G.J.; Emery, E.M. Volatile Fatty Acid Analyses of Blood and Rumen Fluid by Gas Chromatography. J. Dairy Sci. 1961, 44, 1768-1771. [CrossRef]

24. Chaney, A.L.; Marbach, E.P. Modified Reagents for Determination of Urea and Ammonia. Clin. Chem. 1962, 8, 130-132. [CrossRef] [PubMed]

25. AOAC International. Official Methods of Analysis, 18th ed.; AOAC International: Gaithersburg, MD, USA, 2006.

26. Coblentz, W.K.; Abdelgadir, I.E.; Cochran, R.C.; Fritz, J.O.; Fick, W.H.; Olson, K.C.; Turner, J.E. Degradability of Forage Proteins by In Situ and In Vitro Enzymatic Methods. J. Dairy Sci. 1999, 82, 343-354. [CrossRef]

27. Mertens, D.R. Gravimetric determination of amylase-treated neutral detergent fiber in feeds with refluxing in beakers or crucibles: Collaborative study. J. AOAC Int. 2002, 85, 1217-1240.

28. Weiss, W.P. Predicting Energy Values of Feeds. J. Dairy Sci. 1993, 76, 1802-1811. [CrossRef]

29. Grabber, J.H.; Zeller, W.E.; Mueller-Harvey, I. Acetone Enhances the Direct Analysis of Procyanidin- and Prodelphinidin-Based Condensed Tannins in Lotus Species by the Butanol-HCl-Iron Assay. J. Agric. Food Chem. 2013, 61, 2669-2678. [CrossRef]

30. Liu, Y.; Jaworski, N.W.; Rojas, O.J.; Stein, H.H. Energy concentration and amino acid digestibility in high protein canola meal, conventional canola meal, and in soybean meal fed to growing pigs. Anim. Feed Sci. Technol. 2016, 212, 52-62. [CrossRef]

31. Terrill, T.H.; Windham, W.R.; Evans, J.J.; Hoveland, C.S. Condensed tannin concentration in sericea lespedeza as influenced by preservation method. Crop Sci. 1990, 30, 219-224. [CrossRef]

32. Salem, H.B.; Makkar, H.P.S.; Nefzaoui, A.; Hassayoun, L.; Abidi, S. Benefit from the association of small amounts of tannin-rich shrub foliage (Acacia cyanophylla Lindl.) with soya bean meal given as supplements to Barbarine sheep fed on oaten hay. Anim. Feed Sci. Technol. 2005, 122, 173-186. [CrossRef]

33. Florou-Paneri, P.; Christaki, E.; Giannenas, I.; Bonos, E.; Skoufos, I.; Tsinas, A.; Tzora, A.; Peng, J. Alternative protein sources to soybean meal in pig diets. J. Food Agric. Environ. 2014, 12, 655-660.

34. Giger-Reverdin, S.; Morand-Fehr, P.; Tran, G. Literature survey of the influence of dietary fat composition on methane production in dairy cattle. Livest. Prod. Sci. 2003, 82, 73-79. [CrossRef]

35. Khorasani, G.R.; Robinson, P.H.; De Boer, G.; Kennelly, J.J. Influence of Canola Fat on Yield, Fat Percentage, Fatty Acid Profile, and Nitrogen Fractions in Holstein Milk. J. Dairy Sci. 1991, 74, 1904-1911. [CrossRef]

36. Clapperton, J.L.; Czerkawski, J.W. Methane production and soluble carbohydrates in the rumen of sheep in relation to the time of feeding and the effects of short-term intraruminal infusions of unsaturated fatty acids. Br. J. Nutr. 1969, 23, 813-826. [CrossRef] [PubMed]

37. Czerkawski, J.W. Fate of metabolic hydrogen in the rumen. Proc. Nutr. Soc. 1972, 31, 141-146. [CrossRef]

38. Komkris, T.; Stanley, R.W.; Morita, K. Effect of Feeds Containing Molasses Fed Separately and Together with Roughage on Digestibility of Rations, Volatile Fatty Acids Produced in the Rumen, Milk Production, and Milk Constituents. J. Dairy Sci. 1965, 48, 714-719. [CrossRef]

39. Storry, J.E.; Hall, A.J.; Johnson, V.W. The effects of increasing amounts of dietary tallow on milk-fat secretion in the cow. J. Dairy Res. 1973, 40, 293-299. [CrossRef]

40. Palmquist, D.L.; Conrad, H.R. High Fat Rations for Dairy Cows. Effects on Feed Intake, Milk and Fat Production, and Plasma Metabolites. J. Dairy Sci. 1978, 61, 890-901. [CrossRef]

41. Paula, E.M.; Monteiro, H.F.; da Silva, L.G.; Benedeti, P.D.B.; Daniel, J.L.P.; Shenkoru, T.; Broderick, G.A.; Faciola, A.P. Effects of replacing soybean meal with canola meal differing in rumen-undegradable protein content on ruminal fermentation and gas production kinetics using 2 in vitro systems. J. Dairy Sci. 2017, 100, 5281-5292. [CrossRef]

42. Kowalczyk, J.; Ørskov, E.R.; Robinson, J.J.; Stewart, C.S. Effect of fat supplementation on voluntary food intake and rumen metabolism in sheep. Br. J. Nutr. 1977, 37, 251-257. [CrossRef]

43. Hernandez-Urdaneta, A.; Coppock, C.E.; McDowell, R.E.; Gianola, D.; Smith, N.E. Changes in Forage-Concentrate Ratio of Complete Feeds for Dairy Cows. J. Dairy Sci. 1976, 59, 695-707. [CrossRef]

44. Sutton, J.D.; Dhanoa, M.S.; Morant, S.V.; France, J.; Napper, D.J.; Schuller, E. Rates of Production of Acetate, Propionate, and Butyrate in the Rumen of Lactating Dairy Cows Given Normal and Low-Roughage Diets. J. Dairy Sci. 2003, 86, $3620-3633$. [CrossRef]

45. Kolver, E.S.; De Veth, M.J. Prediction of Ruminal pH from Pasture-Based Diets. J. Dairy Sci. 2002, 85, 1255-1266. [CrossRef]

46. Grieshop, C.M.; Kadzere, C.T.; Clapper, G.M.; Flickinger, E.A.; Bauer, L.L.; Frazier, R.L.; Fahey, G.C. Chemical and Nutritional Characteristics of United States Soybeans and Soybean Meals. J. Agric. Food Chem. 2003, 51, 7684-7691. [CrossRef] [PubMed]

47. Weaver, D.B.; Rodriguez-Kabana, R.; Cosper, B.H.; Akridge, R.L. Stonewall-A New Soybean Variety for Alabama; Alabama Agricultural Experiment Station, Auburn University: Auburn, AL, USA, 1989; Circular 295. 
48. Calsamiglia, S.; Stern, M.D.; Firkins, J.L. Effects of protein source on nitrogen metabolism in continuous culture and intestinal digestion in vitro. J. Anim. Sci. 1995, 73, 1819-1827. [CrossRef] [PubMed]

49. Brito, A.; Broderick, G. Effects of Different Protein Supplements on Milk Production and Nutrient Utilization in Lactating Dairy Cows. J. Dairy Sci. 2007, 90, 1816-1827. [CrossRef] [PubMed] 